Do health reception policies in the Nordic region recognize the rights of asylumseeking and resettled refugee children?

Barghadouch, Amina; Skovdal, Morten; Nørredam, Marie Louise

Published in:

Health Policy

DOI:

10.1016/j.healthpol.2019.09.001

Publication date:

2019

Document version

Peer reviewed version

Document license:

Unspecified

Citation for published version (APA):

Barghadouch, A., Skovdal, M., \& Nørredam, M. L. (2019). Do health reception policies in the Nordic region recognize the rights of asylum-seeking and resettled refugee children? Health Policy, 123(12), 1173-1184. https://doi.org/10.1016/j.healthpol.2019.09.001 


\title{
Do health reception policies in the Nordic region recognize the rights of asylum-seeking and resettled refugee children?
}

\author{
Amina Barghadouch*, Morten Skovdal, Marie Norredam \\ Research Centre for Migration, Ethnicity and Health (MESU), Section for Health Services Research, Department of Public Health, University of Copenhagen, \\ Øster Farimagsgade 5, 1014 Copenhagen K, Denmark
}

\section{A R T I C L E I N F O}

\section{Article history:}

Received 6 December 2017

Received in revised form 2 September 2019

Accepted 6 September 2019

\section{Keywords:}

Health reception

Refugee children

Nordic countries

Policy document

UN Convention on the Rights of the Child (CRC)

Safeguarding health

\begin{abstract}
A B S T R A C T
According to the United Nations Committee on the Rights of the Child, it is critical that refugee children's rights are upheld in all national policies covering vulnerable children. This article examines how health policies in the Nordic region recognize the health needs of newly arrived refugee children, and whether these policies respect their individual rights. The article maps out, compares and contrasts health reception policies in Denmark, Finland, Norway and Sweden, paying particular attention to how each addresses the rights and needs of refugee children. The policy documents were obtained through desk-research conducted from January 2017-January 2018. We analysed 34 national laws and guidelines that support the health reception of refugee children. We find that only a few health reception policies across the Nordic region have been written specifically for refugee children. The policies identified predominantly recognize refugee children's right of access to somatic healthcare services, and to emergency services. Their rights to mental health services or broader health-enabling contexts were addressed to a lesser extent. We conclude that there is a need for further recognition of refugee children as rights-holders, and for the intentions of health reception policies to be expanded to include mental health services and healthpromoting initiatives. Further research is needed on whether and how the current policies play out in actual health reception practices.
\end{abstract}

(c) 2019 Elsevier B.V. All rights reserved.
"Refugee children share certain universal human rights, have additional rights as children and particular rights as refugees" [1]

\section{Introduction}

The Nordic region, spearheaded by Sweden, received around a fourth of all children seeking asylum in Europe, following the 2015 influx of refugees. However, a recent study has noted significant concerns as to the level of protection offered by the Nordic countries to these asylum-seeking children [2]. There is an urgent need to take stock of the rights-based intentions of Nordic policies targeting refugee children, and to highlight differences in policies among the Nordic countries. In this context, we seek to map out and compare the health reception policies that relate to refugee children.

Marta Maurás, the former vice chair of the United Nations Committee on the Rights of the Child, has argued that, for children

\footnotetext{
* Corresponding author at: University of Copenhagen, Department of Public Health, Section for Health Services Research, Øster Farimagsgade 5 DK-1014 Copenhagen K, Denmark.

E-mail address: ambar@sund.ku.dk (A. Barghadouch).
}

to be considered as rights-holders in society, and in accordance with the United Nations Convention on the Rights of the Child (CRC), a legal framework is pivotal. This legal framework must recognize children's specific needs, and sustain the implementation of policies and plans [3]. Nonetheless, a recent report by Innocenti (UNICEF's Office of Research) focusing on Nordic countries' responses to asylum-seeking children, shows that these children experience gaps both in protection and in access to a range of services. The report concludes that there is a general lack of respect of children's rights in the Nordic response to asylum-seeking children [4]. Whilst the report does cover healthcare, it is limited to general healthcare access and focused on the perspectives of key informants. To build on this work, we examine whether and how asylum-seeking and resettled refugee children below the age of 18 (hereafter refugee children) are recognized as citizens with unique needs and rights in national health policies in four Nordic countries. We do this by mapping out, comparing and contrasting the policy intentions of health reception policies for refugee children across Denmark, Finland, Norway and Sweden. We then examine whether and how refugee children feature as individual rights-holders in these policies. 
Health reception is a concept with no formal definition, but has previously been conceptualized as health screenings of newly arrived adult migrants $[5,6]$ and as the initial and ongoing access to healthcare among accompanied asylum-seeking children in the Nordic countries [7]. In this article, we seek to expand the term to refer to initiatives that safeguard the health of refugee children, irrespective of whether the services are offered upon arrival (as screenings), during the asylum-seeking process, or immediately after obtainment of residency in the new country. These early healthcare initiatives are crucial for three reasons. First, several studies have demonstrated a high prevalence of infections, oral health problems, nutritional deficiencies and mental health problems among newly arrived refugee children [8-14]. Health reception initiatives enable early identification and treatment of these somatic and mental health problems [5]. In many countries, protecting the host population against spread of infections among refugees is a primary aim of the health reception [5,15]. Second, studies from the Nordic region repeatedly show that resettled refugee children face significant barriers in accessing health services, whether pertaining to psychiatric healthcare [16] or to preventive healthcare and vaccinations in the national healthcare system [17]. Health reception initiatives offer an important first contact with health services in the country of destination, introducing refugee children and their families to a new healthcare system. Health reception initiatives are therefore not only valuable for refugee children's immediate health needs, but also shape their future capacity to access and navigate the healthcare system [18]. Finally, host countries are likely to benefit from health reception initiatives for refugee children, both by improving public health and by reducing expenses in later healthcare [2].

\subsection{Refugee children as rights-holders in the Nordic region}

Children make up a growing number of the world's refugee population, and now constitute more than half of all refugees around the world [19]. Between 2015 and 2018, about 1.2 million children made their way to Europe, seeking protection and security. More than 130,000 of these children arrived in the Nordic region either accompanied by their families or on their own (about 38\%) $[2,20]$. Compared to other European countries the Nordic countries, and Sweden in particular, have over the past five years granted asylum to an especially large number of children [21]. In 2015 alone, Sweden granted asylum to nearly $40 \%$ of all unaccompanied asylum-seeking children in Europe [22]. However, due to changes in asylum and immigration laws and policies, resulting in various new measures including tighter border controls, the number of people seeking asylum has dropped significantly since 2016 . Nonetheless, the Nordic region's responsibility to protect the rights and health needs of refugee children is continuously on the political agenda [2]. The Nordic countries have historically been frontrunners in welcoming migrants and refugees, in safeguarding and protecting vulnerable children, and in offering universal healthcare. Despite Hjern and Østergaard having found that the Nordic countries grant refugee children broader entitlements to primary healthcare and health assessments compared to other European countries [23,24], the findings of the Innocenti report are disconcerting and call for further scrutiny.

The Nordic countries in many respects share geographical, historical, linguistic, cultural, and social and welfare structures, and all have ratified the $\mathrm{CRC}$, which stresses the importance of refugee children's rights to health and well-being [25]. However, there are differences concerning how each Nordic nation recognizes and approaches refugee children's rights $[7,26]$. Whether and how national health reception policies recognize the rights of refugee children may in turn depend on how the nations consider refugee children as either in need of, and entitled to, protection, or as threats to the existing welfare system. Researchers from Sweden and the UK have described how refugee children are situated in the intersection between nation states' obligations to safeguard children's rights and the right of nations to control immigration [27-29], positioning children as either victims with a right to services or as threats to be controlled through restrictive policies [30]. According to the Innocenti report, the Nordic countries position refugee children primarily as migrants [2].

Other ways of positioning children which may influence the way health reception policies address the rights of refugee children, are whether they are treated as either individual rights-holders or as vulnerable and dependent on adults [31,32]. Refugee children who migrate with families are often positioned as "passive dependents" in family units [33]. Vitus and Lidén argue that the positioning of accompanied asylum-seeking children as part of a family unit, makes it easier for nation states to avoid taking responsibility for the protection of asylum-seeking children, and instead place the responsibility of children in the hands of their parents [26]. Unaccompanied refugee children, on the other hand, because of the absence of their family upon arrival, are considered to be amongst the most vulnerable children in the world [34]. This, coupled with their greater risk of developing mental and psychiatric health problems [11,35], has resulted in a large policy and research focus specifically on unaccompanied children compared to their accompanied peers [33]. For example, unaccompanied children, having individual rights, are therefore always assigned a legal representative, whereas there seems to be an expectation that the best interests of accompanied asylum-seeking children correspond to those of their parents [2] - hence, effectively these (accompanied) children are not recognized as having individual rights of their own. In terms of differences in the Nordic region, Vitus and Lidén have found that accompanied asylum-seeking children in the Danish asylum system are positioned as family dependents and as asylum-seekers, while in Norway they are first and foremost positioned as children with individual rights [26]. Positioning refugee children as either family dependents or as migrants runs the risk of overlooking their specific needs, as well as failing to recognize their individual rights as children or refugees.

In mapping out, comparing and contrasting policies that create the context for health reception initiatives in the Nordic region, we have a particular interest in exploring whether and how the unique needs and rights of refugee children are manifested within the policy intentions. In doing so, we not only showcase and offer insights into the characteristics of each country's efforts to safeguard the health and well-being of newly arrived refugee children, but also offer a checklist for critically examining whether and how refugee children feature as rights-holders.

\section{Materials and methods}

\subsection{Data material}

The material used in this study was obtained through desk research conducted from January 2017-January 2018. We searched for and collated policy documents in the form of national laws and guidelines related to the health reception of newly arrived refugee children in Denmark, Finland, Norway and Sweden. The criteria for inclusion of documents were that they had to be i) national, and actively used; ii) legislative, or guiding professionals; iii) make reference to accompanied refugee children; and iv) supportive of initiatives that facilitate the health reception of refugee children. We searched for documents that addressed children in the asylumseeking phase as well as after obtainment of residency. The rights and needs of unaccompanied minors, due to their extraordinary circumstances and vulnerabilities, have traditionally been subject to much policy focus [33]. Therefore, we did not include policies 
that focused exclusively on unaccompanied minors. The documents were identified online through relevant authorities such as ministries and boards dealing with health, immigration, integration, social services or children. Additionally, some documents were identified through references in other policies. Due to language barriers, country experts from Sweden and Finland assisted in the identification of the Swedish and Finnish documents. The documents were then reviewed for their relevance to health reception of refugee children, such as: whether they facilitated initiatives upon arrival in the country; access to healthcare during the asylumphase; health promotion; disease prevention; refugee children's rights to health, well-being and healthcare; or other initiatives that aimed to safeguard newly arrived refugee children's health.

In total, we identified 34 written policies across the four countries, consisting of legislation and guidelines that facilitate the health reception of refugee children. Legislation included either entire laws, specific to children, refugees or health (e.g. legislation on reception of refugees or child healthcare) or specific sections within more general legislation (e.g. laws on health or immigration). The 34 policy documents were made up of nine laws and 25 national guidelines. We assigned an individual ID (identification) number to each of these policies (see Table 1: the initial letter of the ID number corresponds to the relevant country, e.g. D for Danish policy), and translated their titles into English. In total, 11 of the identified policies were from Denmark, eight from Finland, six from Norway and nine from Sweden. Two laws and five guidelines were generic and served the purpose of promoting the health and wellbeing of all children in the respective countries. We included these documents as they were referred to explicitly in the included policies covering refugees. The generic policies specify the entitlements of all children, including children without permanent residency.

For quality assurance purposes, we conducted five individual interviews with key informants from Sweden, Finland and Norway. Colleagues working on the health and integration of refugee youth in these three countries assisted with the recruitment of key informants. A criterium for their selection was knowledge of the legal framework concerning the health reception of refugee children in their respective countries. The informants recruited represented various professional backgrounds: a paediatrician, a lawyer and three academic researchers. The interviews sought to verify the identification of the written policies encompassing data. In the interviews, the key informants were also invited to comment on our tables and analysis, either corroborating and elaborating on our initial analysis, or filling in potential gaps.

\subsection{Analyses}

We conducted two analyses to ascertain whether and how refugee children figured as individual rights-holders in the selected health reception policies. Fig. 1 illustrates our inclusion of health reception policies and use of other documents in the two analyses. In the first analysis, we performed a review and mapping of all 34 policies. This was to provide an overview and to compare and contrast the health reception policies across the four Nordic countries (Table 1).

In the second analysis, we compared the policies in the four countries according to international recommendations for health initiatives for refugee children, along with how the policies recognized refugee children as individual rights-holders. To facilitate this exercise, we devised a list of child-centred health reception initiatives, based on lessons learnt from the United Nations High Commissioner for Refugees (UNHCR) on the protection of refugee children. We reviewed five UNHCR documents targeted both at refugee camps in low- and middle-income countries [13,24] and at resettlement of refugees in high-income countries [1,15,36]. The documents were reviewed for criteria regarding basic health- care services, along with recommendations and guidelines relevant to health reception of refugee children in the Nordic countries. Initiatives or services that were only relevant for low- and middleincome country-contexts were not included. For example, from a checklist in a chapter on health and nutrition in the document "Refugee Children: Guidelines on Protection and Care" (1994) we did not include recommendations on water, sanitation, clothing and nutrition as relevant for a Nordic context. However, we included vaccinations, access to healthcare and training of health professionals [18] as essential initiatives for promoting the health reception of refugee children in the Nordic region. While some of the recommendations were very specific, for instance "vitamin $A$ prophylaxis" [18] or "communicable diseases screening" [36], others were broader, such as "protection and healthy development of refugee children" [1] or "children know where to get help" [15]. In total, we identified 14 initiatives in the five documents that we deemed relevant as health reception initiatives for refugees in the Nordic region. We clustered these initiatives according to which aspects of refugee children's health they supported: i) somatic health; ii) both somatic and mental health; iii) mental health; and iv) a health-enabling context (see Table 2). Subsequently, we used the 14 initiatives as a checklist to assess the extent to which Nordic policies facilitate health reception initiatives for refugee children. In this analysis, we reviewed the 32 policies that to some extent made reference to the unique needs and rights of refugee children. Two general guidelines for promoting child health and well-being (F7 and N6 in Table 1) did not address refugee children, and were therefore excluded from this analysis. The three general guidelines (D10, S8 and S9; see Fig. 1) that were included in the analysis made brief references to the additional rights of refugee children. We reviewed these health reception policies with the aim of assessing whether and how they responded to the 14 health reception initiatives derived from the UNHCR documents. Table 2 depicts the results of the exercise and a blank field suggests that the initiative is not mentioned in any of the country's written policies. We further examined whether the health reception initiative was targeted at refugee children specifically or to refugees in general (adults or families). Policies that explicitly mentioned a health reception initiative were categorized as either: (i) policy makes specific reference to refugee children, which applied when the policy explicitly recognized refugee children's right to be covered by the terms of the initiative (colored dark gray); or (ii) policy makes specific reference to refugees, which applied when the policy did not specify whether children were entitled to be covered by the terms of the health reception initiative (colored light gray). If a policy from a country made a specific reference to refugee children, policies addressing the same initiative with reference only to adults or families were excluded from Table 2.

\section{Results}

\subsection{What are the existing policies for health reception of refugee children in the Nordic region?}

Table 1 shows the results of the mapping and comparison of health reception policies in 2017 in Denmark, Finland, Norway and Sweden. Twenty of the 34 policies primarily focused on adult migrants and refugees, whereas children were addressed to a much lesser extent. Of the remaining 14 policies, seven focused on children in general (D3, D10, F2, F7, N6, S8 and S9 in Table 1) and six focused on refugee children (D5, D6, D11, F8, N4, N5 and S4). Most of the 34 policies were relevant to asylum-seeking children, except for two Danish policies which addressed refugees who had obtained residency in municipalities (D4 and D9 in Table 1). Further, the majority of the health reception policies were published by national authorities, primarily within health and social affairs, or secondarily within immigration and integration. One Danish policy (D6) was 
Map of Written Health Reception Policies for Refugee Children in Denmark, Finland, Norway and Sweden In 2017.

\begin{tabular}{|c|c|c|c|c|c|c|c|c|}
\hline Country & Type of policy & ID number and title & Last updated & Responsible of policy & Aim of policy & Users of policy & $\begin{array}{l}\text { Relevance to health } \\
\text { reception of refugee } \\
\text { children }\end{array}$ & $\begin{array}{l}\text { Make reference to: all } \\
\text { children (C), refugees (R) } \\
\text { or refugee children (RC) }\end{array}$ \\
\hline \multirow[t]{11}{*}{ Denmark } & \multirow[t]{4}{*}{ Laws } & D1: The Health Act, $\S 80$ [51] & 2016 & Ministry of Health & $\begin{array}{l}\text { Outline rights to } \\
\text { general healthcare }\end{array}$ & $\begin{array}{l}\text { Operators of asylum } \\
\text { centers and health } \\
\text { professionals }\end{array}$ & $\begin{array}{l}\text { Urgent healthcare } \\
\text { during asylum-seeking } \\
\text { phase }\end{array}$ & $\mathrm{R}$ \\
\hline & & D2: The Aliens Act, §42a [52] & 2017 & $\begin{array}{l}\text { Ministry of } \\
\text { Immigration and } \\
\text { Integration }\end{array}$ & $\begin{array}{l}\text { Outline rights to } \\
\text { general healthcare }\end{array}$ & $\begin{array}{l}\text { Operators of asylum } \\
\text { centers and health } \\
\text { professionals }\end{array}$ & $\begin{array}{l}\text { Urgent healthcare } \\
\text { during asylum-seeking } \\
\text { phase }\end{array}$ & $\mathrm{R}$ \\
\hline & & $\begin{array}{l}\text { D3: Act on preventive } \\
\text { healthcare services to children } \\
\text { and adolescents [53] }\end{array}$ & 2010 & Ministry of Health & $\begin{array}{l}\text { Outline rights to } \\
\text { preventive healthcare }\end{array}$ & Health professionals & $\begin{array}{l}\text { Preventive healthcare } \\
\text { during asylum-seeking } \\
\text { phase and in } \\
\text { municipalities }\end{array}$ & c \\
\hline & & $\begin{array}{l}\text { D4: Act on offer of } \\
\text { health-related assessment of } \\
\text { newly arrived refugees and } \\
\text { family-reunified to refugees } \\
\text { [54] }\end{array}$ & 2016 & $\begin{array}{l}\text { Ministry of } \\
\text { Immigration and } \\
\text { Integration }\end{array}$ & $\begin{array}{l}\text { Outline rights and } \\
\text { duties related to } \\
\text { municipal health } \\
\text { assessments }\end{array}$ & $\begin{array}{l}\text { Social workers and } \\
\text { health professionals in } \\
\text { municipalities }\end{array}$ & $\begin{array}{l}\text { Health assessment in } \\
\text { municipalities }\end{array}$ & $\mathrm{R}$ \\
\hline & \multirow[t]{7}{*}{ Guidelines } & $\begin{array}{l}\text { D5: Guidelines for allocation of } \\
\text { health-related services to } \\
\text { asylum-seeker children and } \\
\text { children with illegal residency } \\
\text { in Denmark [39] }\end{array}$ & 2015 & $\begin{array}{l}\text { Office for Provision, } \\
\text { Immigration Service }\end{array}$ & $\begin{array}{l}\text { Guidelines for general } \\
\text { healthcare }\end{array}$ & $\begin{array}{l}\text { Operators of asylum } \\
\text { centers and health } \\
\text { professionals }\end{array}$ & $\begin{array}{l}\text { General healthcare } \\
\text { during asylum-seeking } \\
\text { phase }\end{array}$ & $\mathrm{RC}$ \\
\hline & & $\begin{array}{l}\text { D6: Standard for psychological } \\
\text { screenings of minor } \\
\text { asylum-seekers [55] }\end{array}$ & 2015 & $\begin{array}{l}\text { The Psychological Unit, } \\
\text { Danish Red Cross }\end{array}$ & $\begin{array}{l}\text { Guidelines for } \\
\text { psychological } \\
\text { screenings }\end{array}$ & $\begin{array}{l}\text { Professionals in asylum } \\
\text { centers responsible of } \\
\text { psychological } \\
\text { screenings }\end{array}$ & $\begin{array}{l}\text { Psychological } \\
\text { screening during } \\
\text { asylum-seeking phase }\end{array}$ & $\mathrm{RC}$ \\
\hline & & D7. Migrants' health [56] & 2017 & $\begin{array}{l}\text { The Danish Health and } \\
\text { Medicines Authority }\end{array}$ & $\begin{array}{l}\text { Guidelines for } \\
\text { vaccinations }\end{array}$ & $\begin{array}{l}\text { Health professionals in } \\
\text { asylum centers and } \\
\text { hospitals }\end{array}$ & Vaccinations & $\mathrm{R}$ \\
\hline & & $\begin{array}{l}\text { D8. Information about the } \\
\text { health-related challenges in } \\
\text { relation to the current refugee } \\
\text { situation [57] }\end{array}$ & 2015 & $\begin{array}{l}\text { The Danish Health and } \\
\text { Medicines Authority }\end{array}$ & $\begin{array}{l}\text { Guidelines for general } \\
\text { healthcare }\end{array}$ & $\begin{array}{l}\text { Employees in regions } \\
\text { and asylum centers }\end{array}$ & Vaccinations & $\mathrm{R}$ \\
\hline & & $\begin{array}{l}\text { D9: Professional instructions to } \\
\text { general practitioners and other } \\
\text { physicians, who perform } \\
\text { health assessments of newly } \\
\text { arrived refugees and } \\
\text { family-reunified to refugees } \\
\text { [58] }\end{array}$ & 2015 & $\begin{array}{l}\text { National Board of } \\
\text { Social Services }\end{array}$ & $\begin{array}{l}\text { Guidelines for } \\
\text { municipal health } \\
\text { assessments }\end{array}$ & $\begin{array}{l}\text { Physicians who } \\
\text { perform health } \\
\text { assessments in } \\
\text { municipalities }\end{array}$ & $\begin{array}{l}\text { Health assessment in } \\
\text { municipalities }\end{array}$ & $\mathrm{R}$ \\
\hline & & $\begin{array}{l}\text { D10: Guideline on preventive } \\
\text { healthcare services to children } \\
\text { and adolescents [37] }\end{array}$ & 2011 & $\begin{array}{l}\text { The Danish Health and } \\
\text { Medicines Authority }\end{array}$ & $\begin{array}{l}\text { Guidelines for } \\
\text { preventive healthcare }\end{array}$ & Health professionals & $\begin{array}{l}\text { General preventive } \\
\text { healthcare }\end{array}$ & c \\
\hline & & $\begin{array}{l}\text { D11: Contract between Danish } \\
\text { Red Cross and the Danish } \\
\text { Immigration Service on } \\
\text { accommodation and support }\end{array}$ & 2017 & $\begin{array}{l}\text { Ministry of } \\
\text { Immigration and } \\
\text { Integration, The } \\
\text { Immigration Service }\end{array}$ & $\begin{array}{l}\text { Guidelines for initial } \\
\text { health assessments }\end{array}$ & $\begin{array}{l}\text { Operators of asylum } \\
\text { centers and health } \\
\text { professionals }\end{array}$ & $\begin{array}{l}\text { Health examinations in } \\
\text { asylum centers and } \\
\text { other health reception } \\
\text { initiatives }\end{array}$ & $\mathrm{RC}$ \\
\hline
\end{tabular}


Table 1 (Continued)

\begin{tabular}{|c|c|c|c|c|c|c|c|c|}
\hline Country & Type of policy & ID number and title & Last updated & Responsible of policy & Aim of policy & Users of policy & $\begin{array}{l}\text { Relevance to health } \\
\text { reception of refugee } \\
\text { children }\end{array}$ & $\begin{array}{l}\text { Make reference to: all } \\
\text { children }(C) \text {, refugees }(R) \\
\text { or refugee children }(R C)\end{array}$ \\
\hline \multirow[t]{8}{*}{ Finland } & \multirow[t]{2}{*}{ Laws } & $\begin{array}{l}\text { F1: Act on reception of persons } \\
\text { seeking international } \\
\text { protection and identification of } \\
\text { and support to victims of } \\
\text { human trafficking, } \S 5, \S 13 \text { and } \\
\S 26[60]\end{array}$ & 2011 & Ministry of the Interior & $\begin{array}{l}\text { Outline rights to } \\
\text { healthcare }\end{array}$ & $\begin{array}{l}\text { Operators of asylum } \\
\text { centers and health } \\
\text { professionals }\end{array}$ & $\begin{array}{l}\text { General healthcare } \\
\text { during asylum-seeking } \\
\text { phase }\end{array}$ & $\mathrm{R}$ \\
\hline & & $\begin{array}{l}\text { F2: The Health Care Act, } \S 15- \\
\S 16[61]\end{array}$ & 2010 & $\begin{array}{l}\text { Ministry of Social } \\
\text { Affairs and Health }\end{array}$ & $\begin{array}{l}\text { Outline rights to school } \\
\text { healthcare }\end{array}$ & $\begin{array}{l}\text { Operators of asylum } \\
\text { centers and health } \\
\text { professionals }\end{array}$ & $\begin{array}{l}\text { General healthcare } \\
\text { during asylum-seeking } \\
\text { phase }\end{array}$ & C \\
\hline & \multirow[t]{6}{*}{ Guidelines } & $\begin{array}{l}\text { F3: Guidelines for health care } \\
\text { services related to infection } \\
\text { prevention [62] }\end{array}$ & 2016 & $\begin{array}{l}\text { National Institute for } \\
\text { Health and Welfare }\end{array}$ & $\begin{array}{l}\text { Outline health } \\
\text { professionals' } \\
\text { responsibilities }\end{array}$ & $\begin{array}{l}\text { Health professionals } \\
\text { performing health } \\
\text { examinations }\end{array}$ & $\begin{array}{l}\text { Health examination in } \\
\text { asylum centers }\end{array}$ & $\mathrm{R}$ \\
\hline & & $\begin{array}{l}\text { F4: Notable symptoms and } \\
\text { infectious diseases in asylum } \\
\text { seekers [63] }\end{array}$ & 2016 & $\begin{array}{l}\text { National Institute for } \\
\text { Health and Welfare }\end{array}$ & $\begin{array}{l}\text { Guidelines for } \\
\text { recognition of } \\
\text { symptoms }\end{array}$ & $\begin{array}{l}\text { Employees and health } \\
\text { professionals in asylum } \\
\text { centers }\end{array}$ & Vaccinations & $\mathrm{R}$ \\
\hline & & $\begin{array}{l}\text { F5: Prevention of refugees' and } \\
\text { asylum-seekers' infection } \\
\text { problem [64] }\end{array}$ & 2010 & $\begin{array}{l}\text { Ministry of Social } \\
\text { Affairs and Health with } \\
\text { THL }\end{array}$ & $\begin{array}{l}\text { Guidelines for general } \\
\text { healthcare }\end{array}$ & $\begin{array}{l}\text { Health professionals } \\
\text { organizing and } \\
\text { performing screenings } \\
\text { of infections }\end{array}$ & $\begin{array}{l}\text { Screening for } \\
\text { infections, vaccinations } \\
\text { and information during } \\
\text { the asylum-seeking } \\
\text { phase }\end{array}$ & $\mathrm{R}$ \\
\hline & & $\begin{array}{l}\text { F6: Social- and healthcare } \\
\text { services for asylum-seekers at } \\
\text { asylum centers and the } \\
\text { municipalities' roles [65] }\end{array}$ & 2016 & $\begin{array}{l}\text { Local Finland } \\
\text { (Kommunforbundet) }\end{array}$ & $\begin{array}{l}\text { Outline responsibilities } \\
\text { regarding social- and } \\
\text { healthcare }\end{array}$ & $\begin{array}{l}\text { Municipalities and } \\
\text { health professionals }\end{array}$ & $\begin{array}{l}\text { General healthcare } \\
\text { during asylum-seeking } \\
\text { phase }\end{array}$ & $\mathrm{R}$ \\
\hline & & $\begin{array}{l}\text { F7: Recommendations, School- } \\
\text { and student healthcare and } \\
\text { preventive oral and dental care } \\
{[66]}\end{array}$ & 2010 & $\begin{array}{l}\text { Ministry of Social } \\
\text { Affairs and Health }\end{array}$ & $\begin{array}{l}\text { Guidelines for } \\
\text { preventive healthcare }\end{array}$ & $\begin{array}{l}\text { Municipalities and } \\
\text { health professionals }\end{array}$ & $\begin{array}{l}\text { General preventive } \\
\text { healthcare }\end{array}$ & C \\
\hline & & $\begin{array}{l}\text { F8: Recommendation for } \\
\text { Municipalities: Right to } \\
\text { healthcare services for migrant } \\
\text { children and pregnant women } \\
\text { [67] }\end{array}$ & 2017 & $\begin{array}{l}\text { Ministry of Social } \\
\text { Affairs and Health }\end{array}$ & $\begin{array}{l}\text { Outline migrant } \\
\text { children's rights to } \\
\text { healthcare }\end{array}$ & $\begin{array}{l}\text { Municipalities and } \\
\text { health professionals }\end{array}$ & $\begin{array}{l}\text { General healthcare for } \\
\text { different groups of } \\
\text { children }\end{array}$ & RC \\
\hline \multirow[t]{4}{*}{ Norway } & \multirow[t]{2}{*}{ Laws } & $\begin{array}{l}\mathrm{N} 1 \text { : Act on right to healthcare } \\
\text { for persons without residency } \\
\text { [68] }\end{array}$ & 2015 & $\begin{array}{l}\text { Ministry of Health and } \\
\text { Care Services }\end{array}$ & $\begin{array}{l}\text { Outline rights to } \\
\text { healthcare }\end{array}$ & $\begin{array}{l}\text { Operators of asylum } \\
\text { centers and health } \\
\text { professionals }\end{array}$ & $\begin{array}{l}\text { General healthcare } \\
\text { during asylum-seeking } \\
\text { phase }\end{array}$ & $\mathrm{R}$ \\
\hline & & $\begin{array}{l}\text { N2: Act on Tuberculosis } \\
\text { Control, } \S 3-1,3-2 \text { [69] }\end{array}$ & 2009 & $\begin{array}{l}\text { Ministry of Health and } \\
\text { Care Services }\end{array}$ & $\begin{array}{l}\text { Outline prevention of } \\
\mathrm{TB}\end{array}$ & $\begin{array}{l}\text { Operators of asylum } \\
\text { centers and health } \\
\text { professionals }\end{array}$ & $\begin{array}{l}\text { Mandatory TB } \\
\text { screening in asylum } \\
\text { centers }\end{array}$ & $\mathrm{R}$ \\
\hline & \multirow[t]{2}{*}{ Guidelines } & $\begin{array}{l}\text { N3: Guideline for the } \\
\text { healthcare service offer to } \\
\text { asylum-seekers, refugees and } \\
\text { family-reunified [40] }\end{array}$ & 2016 & $\begin{array}{l}\text { The Norwegian } \\
\text { Directorate of Health }\end{array}$ & $\begin{array}{l}\text { Guidelines for } \\
\text { healthcare }\end{array}$ & $\begin{array}{l}\text { Operators of asylum } \\
\text { centers and health } \\
\text { professionals }\end{array}$ & $\begin{array}{l}\text { Health examinations in } \\
\text { asylum centers and } \\
\text { several other health } \\
\text { reception initiatives }\end{array}$ & $\mathrm{R}$ \\
\hline & & $\begin{array}{l}\text { N4: Information Plan for } \\
\text { Children and Adolescents in } \\
\text { asylum centers [70] }\end{array}$ & 2010 & $\begin{array}{l}\text { The Norwegian } \\
\text { Directorate of } \\
\text { Immigration }\end{array}$ & $\begin{array}{l}\text { Guidelines for } \\
\text { provision of } \\
\text { information }\end{array}$ & $\begin{array}{l}\text { Employees in asylum } \\
\text { centers }\end{array}$ & $\begin{array}{l}\text { Information about } \\
\text { health system and } \\
\text { rights to } \\
\text { asylum-seeking } \\
\text { children between } \\
12-18 \text { years }\end{array}$ & RC \\
\hline
\end{tabular}


Table 1 (Continued)

\begin{tabular}{|c|c|c|c|c|c|c|c|c|}
\hline Country & Type of policy & ID number and title & Last updated & Responsible of policy & Aim of policy & Users of policy & $\begin{array}{l}\text { Relevance to health } \\
\text { reception of refugee } \\
\text { children }\end{array}$ & $\begin{array}{l}\text { Make reference to: all } \\
\text { children }(\mathrm{C}) \text {, refugees }(\mathrm{R}) \\
\text { or refugee children }(\mathrm{RC})\end{array}$ \\
\hline & & $\begin{array}{l}\text { N5: Young in Norway, Module } \\
\text { 7: Health [71] }\end{array}$ & - & $\begin{array}{l}\text { The Norwegian } \\
\text { Directorate of } \\
\text { Immigration }\end{array}$ & $\begin{array}{l}\text { Guidelines for } \\
\text { provision of } \\
\text { information }\end{array}$ & $\begin{array}{l}\text { Teachers in asylum } \\
\text { centers }\end{array}$ & $\begin{array}{l}\text { Information about } \\
\text { health system and } \\
\text { rights to } \\
\text { asylum-seeking } \\
\text { children between } \\
12-18 \text { years }\end{array}$ & $\mathrm{RC}$ \\
\hline & & $\begin{array}{l}\text { N6: National professional } \\
\text { guideline on the } \\
\text { health-promoting and } \\
\text { preventive work in health } \\
\text { stations, school-healthcare and } \\
\text { health stations for adolescents } \\
\text { [72] }\end{array}$ & 2017 & $\begin{array}{l}\text { The Norwegian } \\
\text { Directorate of Health }\end{array}$ & $\begin{array}{l}\text { Guidelines for general } \\
\text { healthcare }\end{array}$ & Health professionals & $\begin{array}{l}\text { General preventive } \\
\text { healthcare }\end{array}$ & c \\
\hline \multirow[t]{9}{*}{ Sweden } & Laws & $\begin{array}{l}\text { S1: Act on Health Services and } \\
\text { Healthcare to Asylum-seekers } \\
\text { etc. [73] }\end{array}$ & 2008 & Ministry of Justice & $\begin{array}{l}\text { Outline rights to } \\
\text { healthcare }\end{array}$ & $\begin{array}{l}\text { Operators of asylum } \\
\text { centers and health } \\
\text { professionals }\end{array}$ & $\begin{array}{l}\text { Healthcare and health } \\
\text { examination during } \\
\text { asylum-seeking phase }\end{array}$ & $\mathrm{R}$ \\
\hline & Guidelines & $\begin{array}{l}\text { S2: The National Board of } \\
\text { Health and Welfare's } \\
\text { guidelines and advice on } \\
\text { health examination of } \\
\text { asylum-seekers etc. [74] }\end{array}$ & 2012 & $\begin{array}{l}\text { The National Board of } \\
\text { Health and Welfare }\end{array}$ & $\begin{array}{l}\text { Guidelines for health } \\
\text { examinations }\end{array}$ & $\begin{array}{l}\text { Operators of asylum } \\
\text { centers and health } \\
\text { professionals }\end{array}$ & $\begin{array}{l}\text { Health examination } \\
\text { during asylum-seeking } \\
\text { phase }\end{array}$ & $\mathrm{R}$ \\
\hline & & $\begin{array}{l}\text { S3: Individual health } \\
\text { conversation, Physical } \\
\text { Examination and Testing } \\
{[41,75,76]}\end{array}$ & 2015 & $\begin{array}{l}\text { The National Board of } \\
\text { Health and Welfare }\end{array}$ & $\begin{array}{l}\text { Guidelines for health } \\
\text { examinations }\end{array}$ & Health professionals & $\begin{array}{l}\text { Health examination } \\
\text { during asylum-seeking } \\
\text { phase }\end{array}$ & $\mathrm{R}$ \\
\hline & & $\begin{array}{l}\text { S4: Migration and children's } \\
\text { health [Child health care for } \\
\text { children who migrated from } \\
\text { other countries] [77] }\end{array}$ & 2017 & $\begin{array}{l}\text { National Guidelines on } \\
\text { Child Health }\end{array}$ & $\begin{array}{l}\text { Guidelines for } \\
\text { provision of healthcare }\end{array}$ & $\begin{array}{l}\text { Operators of asylum } \\
\text { centers and health } \\
\text { professionals }\end{array}$ & $\begin{array}{l}\text { Health examination } \\
\text { during asylum-seeking } \\
\text { phase }\end{array}$ & $\mathrm{RC}$ \\
\hline & & $\begin{array}{l}\text { S5: Guideline for health } \\
\text { examinations for migrants. } \\
\text { Meetings on health [78] }\end{array}$ & 2014 & $\begin{array}{l}\text { The Public Health } \\
\text { Agency of Sweden }\end{array}$ & $\begin{array}{l}\text { Guidelines for health } \\
\text { examinations }\end{array}$ & $\begin{array}{l}\text { Health professionals } \\
\text { performing health } \\
\text { examinations }\end{array}$ & $\begin{array}{l}\text { Organisation of health } \\
\text { examination to } \\
\text { asylum-seekers }\end{array}$ & $\mathrm{R}$ \\
\hline & & $\begin{array}{l}\text { S6: People on flight - guideline } \\
\text { on the protection of infection } \\
\text { transmission to the healthcare } \\
\text { service [79] }\end{array}$ & 2015 & $\begin{array}{l}\text { The Public Health } \\
\text { Agency of Sweden }\end{array}$ & $\begin{array}{l}\text { Guidelines regarding } \\
\text { infections }\end{array}$ & Health professionals & $\begin{array}{l}\text { Screening for } \\
\text { infections, treatment } \\
\text { and vaccinations }\end{array}$ & $\mathrm{R}$ \\
\hline & & $\begin{array}{l}\text { S7: Vaccinations to people on } \\
\text { flight. Recommendations to the } \\
\text { healthcare service [80] }\end{array}$ & 2015 & $\begin{array}{l}\text { The Public Health } \\
\text { Agency of Sweden }\end{array}$ & $\begin{array}{l}\text { Guidelines for } \\
\text { vaccinations }\end{array}$ & Health professionals & Vaccinations & $\mathrm{R}$ \\
\hline & & $\begin{array}{l}\text { S8: Guideline for child } \\
\text { healthcare [38] }\end{array}$ & 2014 & $\begin{array}{l}\text { The National Board of } \\
\text { Health and Welfare }\end{array}$ & $\begin{array}{l}\text { Guidelines for child } \\
\text { healthcare }\end{array}$ & Health professionals & $\begin{array}{l}\text { General preventive } \\
\text { healthcare }\end{array}$ & $\mathrm{R}$ \\
\hline & & $\begin{array}{l}\text { S9: Guidelines for } \\
\text { student-healthcare [81] }\end{array}$ & 2016 & $\begin{array}{l}\text { The National Board of } \\
\text { Health and Welfare and } \\
\text { The Swedish National } \\
\text { Agency for Education }\end{array}$ & $\begin{array}{l}\text { Guidelines for school } \\
\text { healthcare }\end{array}$ & $\begin{array}{l}\text { Health professionals } \\
\text { and schools }\end{array}$ & $\begin{array}{l}\text { General preventive } \\
\text { healthcare }\end{array}$ & $\mathrm{R}$ \\
\hline
\end{tabular}




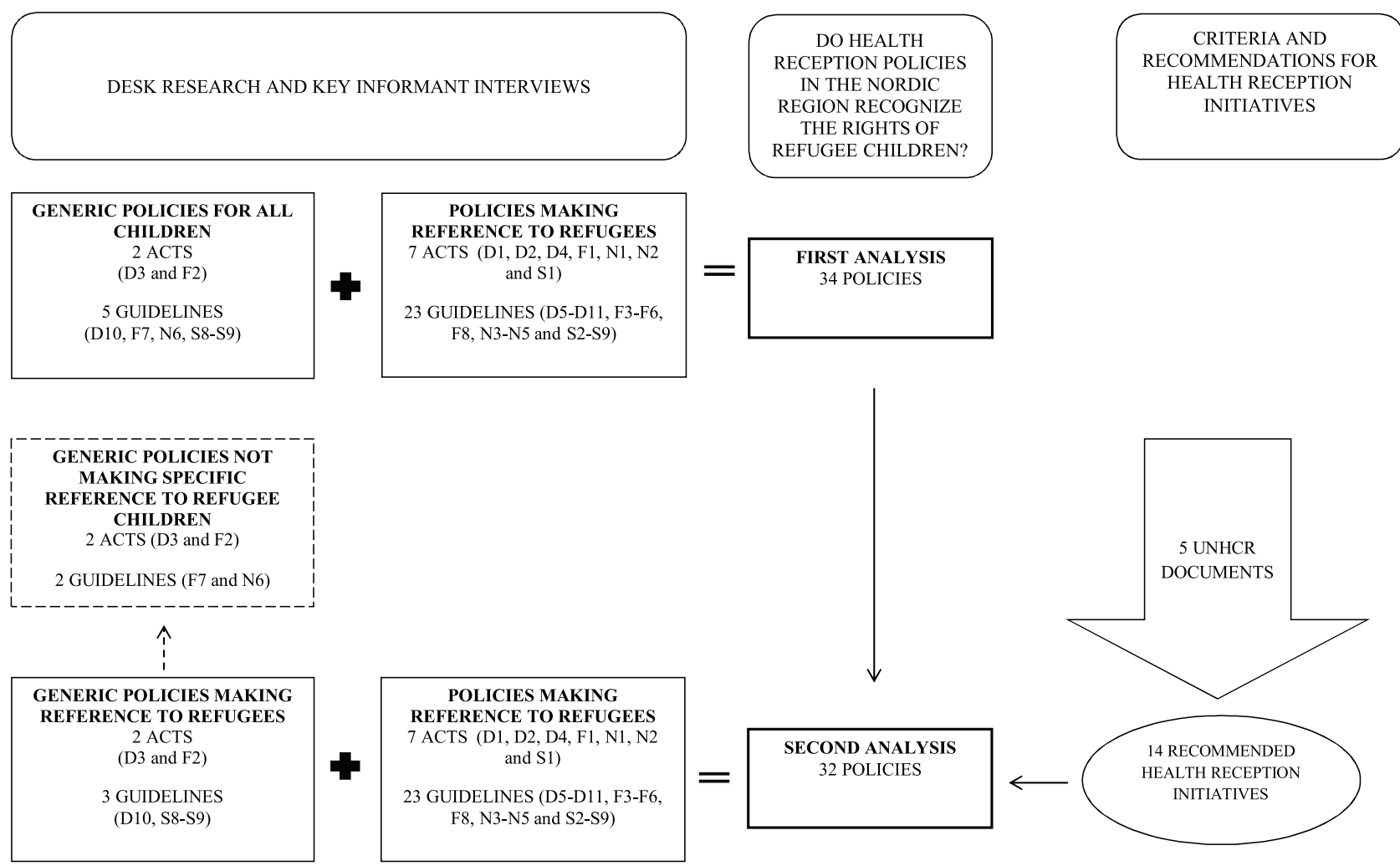

Fig. 1. Overview of policies and documents included in the two analyses.

Table 2

Assessment of Health Reception Policies According to 14 International Recommendations for Health Reception Initiatives to Refugee Children.

\begin{tabular}{|c|c|c|c|c|c|}
\hline & & Denmark & Finland & Norway & Sweden \\
\hline \multirow[t]{3}{*}{ Somatic health } & Vaccination during asylum-phase & D7, D10, D11 & F3, F5, F8 & N3 & S4, S6, S7, S8, S9 \\
\hline & Initial health examination during asylum-phase & D11 & F3, F5 & N3 & $\mathrm{S} 2, \mathrm{~S} 3, \mathrm{~S} 4, \mathrm{~S} 8, \mathrm{~S} 9$ \\
\hline & Oral healthcare during asylum-phase & D5, D11 & F8 & N3 & $\mathrm{S} 2, \mathrm{~S} 3, \mathrm{~S} 4$ \\
\hline \multirow{3}{*}{$\begin{array}{l}\text { Somatic and } \\
\text { mental health }\end{array}$} & Access to national healthcare system during asylum-phase & D3, D5, D11 & $\mathrm{F} 1, \mathrm{~F} 2, \mathrm{~F} 6, \mathrm{~F} 8$ & N1, N3 & S1, S3, S4; S8 \\
\hline & Referral to specialized treatment during asylum-phase & D5* & & \multirow[t]{2}{*}{ N3 } & \multirow[t]{2}{*}{$\mathrm{S} 2, \mathrm{~S} 3$} \\
\hline & Health examination after obtainment of residency & D4, D9 & & & \\
\hline \multirow[t]{2}{*}{ Mental health } & Trauma screening upon arrival to country & D6, D10, D11 & & N3 & $\mathrm{S} 2, \mathrm{~S} 4$ \\
\hline & Mental health service during asylum-phase & D5, D9 & F6 & N3 & S3, S4, S8 \\
\hline \multirow{7}{*}{$\begin{array}{l}\text { Health-enabling } \\
\text { context }\end{array}$} & Information on health and healthcare & D11 & F1, F5 & N3, N4, N5 & $\mathrm{S} 2, \mathrm{~S} 3, \mathrm{~S} 8$ \\
\hline & Dialogue & D6 & F3, F5 & N3 & S2, S3, S4 \\
\hline & Participation & & F1 & N4, N5 & S5 \\
\hline & Family support & & F8 & N3 & S4, S8 \\
\hline & Health promotion (play, school, day-care etc.) & D11 & F8 & N3 & \\
\hline & Training of professionals & & & N3 & S3, S5 \\
\hline & Use of interpreters & D5 & F5 & N3 & S4 \\
\hline
\end{tabular}

*Referral to specialized treatment require approval from the Danish Immigration Service.

Policy makes specific reference to refugee children

Policy makes specific reference to all refugees

published by an NGO (nongovernmental organization), the Danish Red Cross, which operates the reception centers for newly arrived asylum-seekers in Denmark. One policy, S4 from Sweden, was published by a child-centered national authority. An overview of the specific health reception initiatives which are mentioned in the policies is available online in Appendix 1. In the following two sections, we present the mapping and comparison of the laws and guidelines that made direct reference to refugees. We then proceed to provide an overview of the generic two laws and five guidelines for preventive child- and school healthcare.

\subsubsection{Legislation protecting all refugees}

Overall, children were not addressed explicitly in the identified laws that facilitated health reception initiatives, except in the Finnish law on reception of refugees (F1), and to a lesser extent in Norwegian and Swedish laws on healthcare for refugees (N2 and S1). The legislation mainly addressed fundamental rights and access to healthcare for asylum-seekers. However, this right to healthcare was incorporated in different legislation across the four countries: In Denmark, the right was enshrined in legislation on both health and immigration (D1 and D2) whereas in Finland it was 
included in the law on general reception of refugees (F1). Norway and Sweden had specific laws on asylum-seekers' rights to general healthcare (N1 and S1). Aside from these fundamental rights, we identified a Danish law stipulating a health examination for refugees with residency (D4), a Swedish law that also mentioned health examinations for asylum seekers (S1), and a Norwegian law on asylum seekers' obligation to undergo tuberculosis (TB) screening (N2).

\subsubsection{Guidelines to protect all refugees}

The guidelines which we identified as health reception policies across the four countries were targeted at instructing and advising professionals within the health system or asylum centers in their work with refugee children. We found a very large number of guidelines regarding initial health examinations of asylumseeking children. These primarily addressed specific initiatives for the urgent healthcare of newly arrived refugee children including vaccinations and control of infections. However, there were significant differences across the countries (D7, D8, D11, F3, F5, N2, N3, and S1-S6) with respect both to coverage and type of health examinations (see also Appendix 1). For example, TB screening was an independent and mandatory health reception initiative in Norway (see above-mentioned law, N2), yet only a secondary element of a general health examination in the Finnish guidelines (F3). There were further significant differences in whether mental health was an aspect of initial health examinations. For example, a Norwegian guideline incorporated mental health as an element within the initial health examination of asylum-seekers (N3), whereas Finnish guidelines only described somatic health (F3-F5). Apart from initial health examinations, a Danish guideline also promoted psychological screening for vulnerable asylum-seeking children (D6); and two Norwegian guidelines were for provision of information about health and the Norwegian healthcare system (N4 and N5) - in Norway refugee children between 12 and 18 years of age were obliged to participate in such information courses. However, other guidelines across the four countries chiefly addressed voluntary health reception initiatives for refugee children.

\subsubsection{Generic legislation and guidelines for preventive child} healthcare

Across all four countries, we identified legislation specifying that all children irrespective of residence status were entitled to preventive healthcare services to the same extent as nativeborn children (D3, F2, N1 and S1). The guidelines describing these health services, across all four countries, promoted a broad range of healthcare services for children and adolescents, such as consultations with visiting health nurses, vaccinations within the national vaccination program, regular examinations of children's physical development, advice to parents, and so on. However, as described in the Methods section, the guidelines considered refugee children to varying degrees. The Danish guideline (D10) included an appendix regarding "Ethnic minority children", attached to a chapter on children with special needs [37]. Apart from addressing how "ethnicity" and "cultural differences" could affect health behavior among ethnic minority children, this appendix briefly mentioned refugee children in relation to their higher risk of developing mental health problems, infections, nutritional deficiency and oral health problems. The appendix listed these potential health problems as points requiring special attention from health professionals working with refugee children. The same appendix also referred to the immigration authorities' guideline regarding health services for asylum-seeking children (D5). The Swedish general guideline for child healthcare (S8) included a chapter on "Children from other countries" [38]. This chapter addressed refugee children and their rights to an initial health examination, vaccinations, information about healthcare and the system, and their universal access to the healthcare system. Sweden also had a guideline for school healthcare (S9) that included a section on asylum-seeking children's rights. The focus of this section, in addition to the initial health examination, was the alignment of refugee students' immunization status with the national vaccination program. The section also emphasized that asylum-seeking children were entitled to all general services mentioned in the guideline. The Norwegian guideline for child and adolescent healthcare (N6) briefly mentioned unaccompanied refugee children in relation to their mental vulnerability. The Finnish guideline on preventive healthcare for all children (F6) did not make any reference to the unique needs of asylum-seeking or refugee children.

\subsection{How do the policies recognize refugee children's rights to health reception initiatives?}

Table 2 presents the results of the second analysis where we assessed 32 health reception policies across the four countries (26 policies make reference to refugees; six generic policies make reference to refugee children) according to their fulfillment of our checklist of essential health reception initiatives. Overall, policies across the four countries largely corresponded positively to these 14 health reception initiatives, and recognized refugee children's rights as being covered by these initiatives. However, health reception initiatives supporting somatic health were mentioned more frequently across the policies than initiatives promoting mental health and a health-enabling context. We also identified that within each of the four countries, some specific policies addressed several of the 14 health reception initiatives simultaneously: Guidelines from Denmark (D5) and Finland (F8) each addressed five initiatives in reference to refugee children specifically. The Norwegian guideline N3 addressed 13 of the initiatives, although it differed as to whether these initiatives were mentioned in reference to children or to refugees in general. Regarding Sweden, one particular health reception initiative was addressed in several of the country's policies. An example of this is vaccinations specifically for refugee children, which were mentioned in five of the Swedish policies (S4, S6-S9).

In the following three sections, we compare the Nordic countries according to how their health reception policies support somatic health, mental health and a health-enabling context for refugee children (see Table 2).

\subsubsection{Somatic health}

In all four countries, there were policies in place to provide vaccinations and oral healthcare, and to promote access to the national healthcare system for asylum-seeking children. The initial health examination was, as aforementioned, addressed in policies from all countries, and infection control was mentioned as a primary element of this examination (D11, F5, N3 and S2). Furthermore, referral to specialized healthcare was also mentioned in relation to health examinations in Norway and Sweden.

In the Danish guideline for allocation of health services to asylum-seeking children, access to the national healthcare system was explicitly related to the principle of non-discrimination in the CRC (D5). Unlike in Norway and Sweden, where healthcare for asylum-seeking children was arranged within the national healthcare system, in Finland and in Denmark it was arranged through an agreement between the immigration authority and the asylum center operators. In Denmark, operators of asylum centers could therefore not initiate "necessary but non-acute healthcare services" without initial approval from the immigration authorities (D5):

Thus, it is decisive whether there is an acute healthcare need (which is financed by the regions) [through the national health insurance, 
Ed.] or a necessary healthcare service (which is financed by the Danish Immigration Service). [30]

Denmark was the only country which provided a health examination for refugee children who had obtained residency (D4 and D9), and this covered both somatic and mental health initiatives. Denmark was also the only country with a policy explicitly addressing follow-up and referral to specialized healthcare for refugee children (D5). In a Norwegian guideline N3, this was framed as a question of protecting the host country:

Asylum-seekers with need for follow-up should be identified as rapidly as possible to safeguard security in reception centers and in general society. An initial health examination can assist in identifying acute health needs and initiate necessary healthcare. [31]

The TB screening, which was mandatory in Norway only, further reflected this focus.

\subsubsection{Mental health}

We found health reception policies supporting mental health initiatives across all four countries, yet not as often, nor as detailed, as policies on urgent and somatic health. Finnish policies did not provide mental trauma screening upon arrival to the country, and although general mental health initiatives during the asylumseeking period were mentioned in these policies, they were without reference to children. The Finnish guideline for municipalities, F6, repeatedly mentioned "psychosocial support" as a municipal responsibility, with reference, however, to refugees in general. The Norwegian policy N3 addressed both screening for trauma and general mental health services, but not specifically in relation to children.

In policies from the other two countries, both screening for trauma and general mental health initiatives were addressed in reference to refugee children (D5, D6, D9, D10, D11 and S2-S4). However, there were significant differences in the details referring to trauma screening in these policies: While Denmark had a guideline specifically for psychological screenings of vulnerable asylum-seeking children (D6), the Swedish guidelines S2 and S4 only briefly mentioned that health professionals should, in the initial health examinations, be aware of children who had been exposed to traumatic events. The Danish guideline on health examinations for refugees with residency (D9), had two chapters focusing separately on, respectively, adults and children - yet, while the chapter on adults focused on somatic health, the one on children mainly focused on mental health.

\subsubsection{Health-enabling context}

Turning to the topic of health-enabling context, compared to the areas of somatic and mental health there were far more variations amongst the four Nordic countries as to whether, and how, their policies addressed initiatives supporting a health-enabling context for refugee children. Policies across all four countries incorporated initiatives for dialogue with children and use of interpreters in communication, but they differed in their degree of recognition of children in relation to these initiatives. For example, Finnish and Norwegian policies did not make any specific reference to children when addressing dialogue. The Danish guideline mentioned that the psychological screening of asylum-seeking children should be performed as a conversation with the child's parents and not with the child (D6). Swedish policies, however, emphasized refugee children's important role in conversations about health. The guideline S3 had the following section title: "Pay extra attention in conversations with children" [41] and several of the Swedish policies repeatedly emphasized that an individual conversation with every child should be prioritized.
Information on health and healthcare was addressed in policies from all countries. In Norway, all accompanied asylum-seeking children between 12 and 18 years were offered a mandatory course on their rights and duties in their new country of residence. In the guideline N5 for teachers, the course module relating to health was outlined, including information as to which articles in the CRC the module related to. The Swedish guidelines for health examinations of refugees also had an extensive focus on information (S2-S4) and further advised professionals to assist refugee children and their families in contacting healthcare services. In contrast to the Finnish and Norwegian policies, in Sweden information given to children was a key element within the health examination alongside the identification of urgent health needs and control of infections.

We identified varying tendencies across the four countries according to how the remaining initiatives supporting a healthenabling context were addressed in the policies. Illustrated as the light gray fields in Table 2, many policies did not target the various health-enabling initiatives at children specifically. For example, health promotion was mentioned in relation to children in one Norwegian guideline, in a section named "Activity and a meaningful everyday" [40]. This section emphasized that both adults and children are at risk of becoming passive and bored during the asylumseeking phase, and explained why it is important to ensure the provision of activities that minimize this risk. The same document also addressed how schools and daycare institutions play central roles in the health and development of refugee children (N3). Likewise, a Finnish guideline underlined a link between refugee children's right to education and health reception initiatives, as many health reception services are organized within school settings in Finland (F8). Support for the family was addressed with specific reference to refugee children in policies from Norway, Sweden and Finland. For example, in the Swedish generic guideline for preventive child healthcare (S8), health professionals were advised to intensify the contact with children and families that were psycho-socially challenged. The Finnish guideline emphasized the responsibility of government services to support families in their effort to promote the health and well-being of their children (F8).

\section{Discussion}

Our study suggests that the rights of refugee children are not always recognized in Nordic health reception policies. Refugee children constituted the main focus in only six of the 34 identified health reception policies. Nevertheless, the policies of all four countries generally recognized refugee children's rights to health reception initiatives, especially to initiatives promoting somatic health. Thus, initiatives such as vaccinations, initial health examinations supporting urgent health needs, and access to the national healthcare system were all addressed in reference to refugee children, whereas initiatives supporting mental health and a health-enabling context for refugee children were less present across the policies. Sweden and Norway had a greater number of policies that recognized the unique needs and rights of refugee children, compared to Finland and Denmark. Furthermore, Sweden had several policies supporting most of the 14 health reception initiatives in our checklist.

\subsection{Why are refugee children's rights not always recognized in health reception policies?}

Across the policies studied in this article, there was a dominating focus on adult refugees and only secondarily children. For example, the health examination for resettled refugees offered in Danish municipalities is part of a general 'Integration Program', governed through the Danish Integration Act, where the aim is to promote 
labor-market participation among resettled refugees [42]. But how does this 'adult-centrism', and prevailing focus on somatic health, impact the recognition of refugee children as individual rightsholders in health reception policies?

The author Xu [43] has, in the context of North America, argued that refugee children are overlooked in resettlement policies, as a result of two prominent policy objectives - which also sheds light on our findings. First, only refugees' most urgent needs are part of these programs. Second, the primary focus of resettlement services for refugees is employment, whereas health and well-being become means to secure the families with economic self-sufficiency [43]. The 'adult-centrism' relates to a current increased political focus across Nordic countries on labor-market participation as a means of integrating refugees into their new society [44]. We noted a focus on 'health screenings' and other early health reception services, which goes back to a rationale of protecting the general population against the spread of communicable diseases that refugees may be carrying $[5,42,45]$. This rationale is demonstrated clearly through the mandatory TB screening of all asylum-seekers in Norway; and across all four countries control of infection is central to the health examinations offered to newly arrived refugee children. In Sweden, a qualitative study found that adult migrants felt that their actual health needs were overlooked during the initial health examination, due to a focus on identifying infectious diseases [46,47]. This focus is not unique to the Nordic region. A recent study compared migrant children's entitlements to health assessments in $30 \mathrm{EU}$ (European Union) countries and noted that more than half of these countries offered either no health assessment, or only provided mandatory screenings for communicable diseases. The authors conclude that the four Nordic countries included in our study generally provide a wider range of, and therefore more comprehensive, health screening services compared to most other European countries [24]. However, the tendency of health reception policies to support somatic health and to focus on infection-prevention comes at the expense of intentions to address the mental health needs of refugee children. This observation resonates with a recent review which has identified major gaps in the provision of mental health services for refugee children in Europe [48]. The tendency is disconcerting given the poor psychological health experienced by many refugee children [48], even several years after arriving in their new country [49].

\subsection{Future health reception policy and practice}

In 1993 the UNHCR, in their policy on protection of refugee children, expressed a hope that children's rights would be so well integrated into future policies and programs that "a separate policy for children will cease to be necessary" [1]. Earlier in this article, we have argued that policies should be attentive towards refugee children's intersecting rights and needs as humans, as children, and as refugees [1]. Of the 34 policies that we have analyzed, five focused on children in general and seven focused specifically on refugee children. As presented in the analysis, a minority of the seven generic policies recognized refugee children's unique needs and rights, and this only briefly. Despite refugee children, in all of the four Nordic countries, having in principle the exact same rights to healthcare as their native-born peers, we argue that their rights and needs go beyond this entitlement. Thus, as a response to the expressed hope of UNHCR in 1993, our findings demonstrate the existence of very few health reception policies focusing specifically on refugee children, and that the policies addressing refugee children merely focus on urgent health needs and somatic health. We therefore argue that there is yet a need for greater recognition of refugee children's unique needs and rights in health reception policies.
A similar argument has been established in a study on 'Children's Case Workers' in Swedish asylum centers (social workers specifically employed to "safeguard the interests of asylum-seeking children") [29]. Here, the employees experienced challenges in fulfilling children's rights as envisioned in the CRC, due to conflicting policy objectives situating the children as either victims who need help, or as threatening refugees who should be controlled (i.e. threatening the existing welfare system). These conflicting objectives follow an overlooking of children's needs and rights in organizational practices within the asylum centers. Consequently, it is argued in the study that there is a need for more detailed national and regional instructions that facilitate an implementation of a child perspective more clearly [29]. In relation to this, our findings of only a narrow recognition of refugee children's unique needs and rights in the policies we have analyzed, might indicate that children's particular position as refugees is foregrounded compared to their basic rights as children and humans [1]. This is further in line with the point in the report of Innocenti, UNICEF, that migration law is given precedence over the CRC across all the Nordic countries [2].

We have analyzed both the laws and guidelines which provide the policy context for health reception initiatives in the Nordic region. If the policies fail to adequately recognize refugee children as individual rights-holders, this may influence how healthcare and social welfare professionals deliver services. In line with Maurás' argument [3], it may lead to programs and practices where the rights of refugee children are overlooked. However, our study is only able to raise further questions as to whether and how the studied policy intentions affect health reception practices. Conceivably, refugee children's unique needs and rights are recognized in practices, despite not being explicitly recognized in national policy intentions. Norway and Sweden are often perceived as frontrunners regarding child-centered policies, which our study supports to a certain degree. For example, both Norway and Sweden focus on inclusion of children in the asylum-seeking interviews and application [26,28]. However, studies have described how this inclusion of children may, rather than fulfilling their needs, have negative effects on their well-being. Instead, participation of the entire refugee family may be more beneficial for asylum-seeking children $[28,30]$. Thus, explicit mentioning of refugee children's rights in national policies does not necessarily mean that their individual needs are met.

Understanding refugee children as dependent individuals and part of a family-unit may also lead to a belief that these children have needs and individual rights that require action and support from the nation state [30]. Policies are sometimes based on standardized understandings of individuals. In the case of refugee children, this means that their unique needs may be separated from their specific contexts [50]. Thus, to fully understand the unique needs of refugee children, insight into their specific contexts is necessary. Whereas this study has covered whether and how refugee children are considered in national policies, it also calls for illumination of the decisive policy-to-practice link, which needs further research. To obtain knowledge on how refugee children and their rights are taken into consideration in health reception initiatives and practices, future research could use qualitative methods in order to obtain insight into professionals' practices and experiences, along with gaining insight into refugee children's own experiences and beliefs regarding initiatives supporting a healthy start in their new country.

\subsection{Methodological considerations}

There are risks and ambiguities in our argument that deserve mentioning. First, we must emphasize that we have studied policy intentions as reflected in written policies and there may be 
important health reception initiatives which are taken for granted and not mentioned in the policies included in this study. Second, refugee children may be covered by certain services without being mentioned in the written policies that outline these specific services. Our study is thus limited by including only policies that refer directly to refugee children. Third, the notion of health reception in our study includes a broad concept of health, for example 'health promotion' in the checklist of 14 health reception initiatives which we developed. We recognize that the category of 'health-enabling context' may not be captured by the included policies due to its broad reach, which may explain its general absence. However, other national policies, such as those that cater for children's education and social welfare, may include initiatives that promote 'health-enabling contexts'. Fourth, our development of the checklist for health reception initiatives resulted from a review performed by ourselves, and should not be read as an exhaustive list of the initiatives that we consider fundamental to safeguarding the health of refugee children. Rather, it should be seen and treated as a tool for developing recommendations for future health reception initiatives.

\section{Conclusions}

It is a well-established argument that national policies need to recognize and document the specific and unique needs and rights of refugee children. In this study, we find that this recognition is not consistent, nor always present, in health reception policies across the Nordic region. We identified few health reception policies developed specifically for refugee children. However, refugee children's rights to health reception initiatives were recognized widely across the policies - yet with the emphasis being on initiatives for children's urgent health needs and somatic health in general. Thus initiatives promoting mental health and a healthenabling context were only addressed to a lesser degree across the four countries' policies. A larger number of policies from Sweden and Norway incorporated refugee children's rights to health reception initiatives compared to policies from Finland and Denmark. We tentatively conclude that there is a need for a greater recognition of refugee children in national health reception policies. Sweden may be used as a 'good example' as its policies incorporate many health reception initiatives and more often make direct reference to refugee children. However, we have no knowledge as to whether and how these differences also play out in actual health reception practices. Therefore, our conclusions call for further research in order to obtain a better understanding of the importance and effects of recognizing refugee children specifically in national policies. Finally, we have developed and used a checklist of 14 child-centered health reception initiatives. This checklist can be further developed and either used in assessments of existing health reception policies and initiatives, or provide inspiration towards new policies that recognize the rights of refugee children.

\section{Funding}

This work was supported by the Nordic Research Council [grant no. \#74645].

\section{Declaration of Competing Interest}

None.

\section{Acknowledgements}

We thank our colleagues Maili Malin and Henry Ascher for assistance with identifying relevant documents. This article was written as part of the project Coming of Age in Exile (CAGE), which is a Nordic collaborative project running from June 2015-January 2021 (www.cage.ku.dk).

\section{Appendix A. Supplementary data}

Supplementary material related to this article can be found, in the online version, at doi:https://doi.org/10.1016/j.healthpol.2019. 09.001 .

\section{References}

[1] United Nations High Commissioner for Refugees (UNHCR). Policy on refugee children EC/SCP/82. Geneva; 1993.

[2] UNICEF Office of Research. Protected on paper? An analysis of Nordic country responses to asylum-seeking children. Florence; 2018

[3] Maurás M. Public policies and child rights: entering the third decade of the convention on the rights of the child. American Academy of Political and Social Science 2011;633:52-65, http://dx.doi.org/10.1177/0002716210382993.

[4] UNICEF Office for Research Innocenti. PRESS RELEASE: asylum-seeking children in Nordic countries face significant gaps in protection and access to services; 2018 (Accessed 5 March 2019) https://www.unicef-irc.org/ article/1754-press-release-asylum-seeking-children-in-nordic-countriesface-significant-gaps-in.html.

[5] Frederiksen HW, Kamper-Jorgensen Z, Agyemang C, Krasnik A, Norredam $M$. Health-reception of newly arrived documented migrants in Europe-why, whom, what and how? European Journal of Public Health 2013;23:725-6, http://dx.doi.org/10.1093/eurpub/ckt110.

[6] Frederiksen HW, Krasnik A, Nørredam M. Policies and practices in the healthrelated reception of quota refugees in Denmark. Danish Medical Journal 2012;59:A4352.

[7] Sandahl H, Norredam M, Hjern A, Asher H, Nielsen SS. Policies of access to healthcare services for accompanied asylum-seeking children in the Nordic countries. Scandinavian Journal of Public Health 2013;41:630-6, http://dx.doi. org/10.1177/1403494813484555.

[8] Fazel M, Reed RV, Panter-BrickC, Stein A. Mental health of displaced and refugee children resettled in high-income countries: risk and protective factors. Lancet 2012;379:266-82, http://dx.doi.org/10.1016/S0140-6736(11)60051-2.

[9] Williams B, Cassar C, Siggers G, Taylor S. Medical and social issues of child refugees in Europe. Archives of Disease in Childhood 2016;101:839-42, http:// dx.doi.org/10.1136/archdischild-2016-310657.

[10] Ryding E, Leth I. Rapport om flygtningebørns trivsel i skolen - integrationsviden - viden der virker. København; 2014

[11] Hirani K, Payne D, Mutch R, Cherian S. Health of adolescent refugees resettling in high-income countries. Archives of Disease in Childhood 2016;101:670-6, http://dx.doi.org/10.1136/archdischild-2014-307221.

[12] Jervelund SS, Malik S, Ahlmark N, Villadsen SF, Nielsen A, Vitus K. Morbidity, self-perceived health and mortality among non-western immigrants and their descendants in Denmark in a life phase perspective. Journal of Immigrant and Minority Health 2017;19:448-76, http://dx.doi.org/10.1007/s10903-0160347-9.

[13] Matthews $\mathrm{H}$. The geography of children: some ethical and methodological considerations for project and dissertation work. Journal of Geography in Higher Education 1998;22:311-24, http://dx.doi.org/10.1080/03098269885723.

[14] Borsch AS, de Montgomery CJ, Gauffin K, Eide K, Heikkilä E, Smith Jervelund S. Health, education and employment outcomes in young refugees in the Nordic countries: a systematic review. Scandinavian Journal of Public Health 2018 http://dx.doi.org/10.1177/1403494818787099 [Epub ahead of print].

[15] United Nations High Commissioner for Refugees (UNHCR). A framework for the protection of children. Geneva; 2012.

[16] Barghadouch A, Kristiansen M, Jervelund SS, Hjern A, Montgomery E, Norredam M. Refugee children have fewer contacts to psychiatric healthcare services: an analysis of a subset of refugee children compared to Danish-born peers. Social Psychiatry and Psychiatric Epidemiology 2016;51:1125-36, http://dx.doi.org/ 10.1007/s00127-016-1260-1.

[17] Moller SP, Hjern A, Andersen A-MN, Norredam M. Differences in uptake of immunisations and health examinations among refugee children compared to Danish-born children: a cohort study. European Journal of Pediatrics 2016;175:539-49, http://dx.doi.org/10.1007/s00431-015-2663-9.

[18] UNHCR. Refugee children: guidelines on protection and care preface. Geneva; 1994

[19] UNHCR, The UN Refugee Agency, Global Trends. Forced displacement in 2017; 2018.

[20] Eurostat. Asylum and first time asylum applicants by citizenship, age and sex Annual aggregated data (rounded); 2019 (Accessed 23 August 2019) https://appsso.eurostat.ec.europa.eu/nui/show. do?query=BOOKMARK_DS-057066_QID_-5C5BOFBF_UID_-3F171EB0\& layout=TIME,C,X,0;GEO,L,Y,0;CITIZEN,L,Z,0;SEX,L,Z,1;AGE,L,Z,2;ASYL APP,L,Z,3;UNIT,L,Z,4;INDICATORS,C,Z,5;\&zSelection=DS-057066CITIZEN,EXT EU28;DS-057066U.

[21] Eurostat. Asylum and first time asylum applicants - annual aggregated data (rounded); 2018 (Accessed 5 March 2019) https://ec.europa.eu/eurostat/tgm/ table.do? tab=table\&init=1\&language $=$ en\&pcode $=$ tps00191\&plugin=1. 
[22] Eurostat. Almost 90000 unaccompanied minors among asylum seekers registered in the EU in 2015; 2016.

[23] Hjern A, Østergaard LS. Migrant children in Europe: entitlements to health care; 2016.

[24] Hjern A, Stubbe Østergaard L, Nörredam M-L. Health examinations of child migrants in Europe: screening or assessment of healthcare needs? BMJ Paediatrics Open 2019;3:e000411, http://dx.doi.org/10.1136/bmjpo-2018-000411.

[25] UN General Assembly. Convention on the rights of the child; 1989 (Accessed 20 June 2017) http://www.refworld.org/docid/3ae6b38fo.html.

[26] Vitus K, Liden H. The status of the asylum-seeking child in Norway and Denmark: comparing discourses, politics and practices. Journal of Refugee Studies 2010;23:62-81, http://dx.doi.org/10.1093/jrs/feq003.

[27] Hek R, Hughes N, Ozman R. Safeguarding the needs of children and young people seeking asylum in the UK: addressing past failings and meeting future challenges. Child Abuse Review 2012;21:335-48, http://dx.doi.org/10.1002/ car.1202.

[28] Eastmond M, Ascher $\mathrm{H}$. In the best interest of the child? The politics of vulnerability and negotiations for asylum in Sweden. Journal of Ethnic and Migration Studies 2011;37:1185-200, http://dx.doi.org/10.1080/1369183X. 2011.590776.

[29] Ottosson L, Eastmond M, Schierenbeck I. Safeguarding a child perspective in asylum reception: dilemmas of children's case workers in Sweden. Journal of Refugee Studies 2013;26:247-64, http://dx.doi.org/10.1093/jrs/fes024.

[30] Boyden J, Hart J. The statelessness of the world's children. Children's Society 2007:21:237-48, http://dx.doi.org/10.1111/j.1099-0860.2007.00105.x.

[31] Pösö T, Skivenes M, Hestbæk A-D. Child protection systems within the Danish, Finnish and Norwegian welfare states-time for a child centric approach? European Journal of Social Work 2014;17:1369-457, http://dx.doi.org/10.1080/ 13691457.2013.829802.

[32] Gilbert N, Parton N, Skivenes M, editors. Child protection systems: International trends and orientations. New York: Oxford University Press; 2011.

[33] White A, Ní Laoire C, Tyrrell N, Carpena-Méndez F. Children's roles in transnational migration. Journal of Ethnic and Migration Studies 2011;37:1159-70, http://dx.doi.org/10.1080/1369183X.2011.590635.

[34] Eide K, Hjern A. Unaccompanied refugee children-vulnerability and agency. Acta Paediatrica 2013;102:666-8, http://dx.doi.org/10.1111/apa.12258.

[35] Barghadouch A, Carlsson J, Norredam M. Psychiatric disorders and predictors hereof among refugee children in early adulthood. The Journal of Nervous and Mental Disease 2016:1, http://dx.doi.org/10.1097/NMD.0000000000000576.

[36] United Nations High Commissioner for Refugees (UNHCR). Refugee resettlement: an international handbook to guide reception and integration; 2002.

[37] Sundhedsstyrelsen. Vejledning om forebyggende sundhedsydelser til børn og unge. Denmark; 2011.

[38] Socialstyrelsen. Vägledning för barnhälsovården; 2014.

[39] Udlændingestyrelsen. Retningslinjer for bevilling af sundhedsmæssige ydelser til asylansøgerbørn og børn med ulovligt ophold i Danmark; 2015.

[40] Helsedirektoratet. Veileder for helsetjenestetilbudet til asylsøkere, flyktninger og familiegjenforente IS-1022; 2016.

[41] Socialstyrelsen. Individuellt hälsosamtal; 2015 (Accessed 28 November 2017) http://www.socialstyrelsen.se/vardochomsorgforasylsokandemedflera/ halsoundersokning/samtal.

[42] Leemreize M, Sodemann M, Nielsen CM, Hvass AM, Nørredam M. Helbredsundersøgelser af flygtninge bør harmoniseres. Ugeskr Læger; 2016. p. 178.

[43] Xu QA. Child-centered refugee resettlement program in the United States. Journal of Immigrant \& Refugee Studies 2017;5:37-59, http://dx.doi.org/10.1300/ J500v05n03_03.

[44] de Montgomery CJ, Petersen JH, Jervelund SS. Diminishing social inequality between refugee children and their peers growing up in Denmark. Journal of Ethnic and Migration Studies 2018:1-29, http://dx.doi.org/10.1080/1369183X. 2018.1526061.

[45] Yew E. Medical inspection of immigrants at Ellis Island, 1891-1924. Bulletin of the New York Academy of Medicine 1980;56:488-510.

[46] Nkulu Kalengayi FK, Hurtig A-K, Nordstrand A, Ahlm C, Ahlberg BM, LI P, et al. Perspectives and experiences of new migrants on health screening in Sweden. BMC Health Services Research 2015;16:14, http://dx.doi.org/10.1186/s12913015-1218-0.

[47] Lobo Pacheco L, Jonzon R, Hurtig A-K. Health assessment and the right to health in Sweden: asylum seekers' perspectives. PLoS One 2016;11:e0161842, http:// dx.doi.org/10.1371/journal.pone.0161842.

[48] Kadir A, Battersby A, Spencer N, Hjern A. Children on the move in Europe: a narrative review of the evidence on the health risks, health needs and health policy for asylum seeking, refugee and undocumented children. BMJ Paediatrics Open 2019;3:364, http://dx.doi.org/10.1136/bmjpo-2018-000364.

[49] Montgomery E. Trauma and resilience in young refugees: a 9-year follow-up study. Development and Psychopathology 2010;22:477, http://dx.doi.org/10. 1017/S0954579410000180.

[50] Zetter R. Labelling refugees: forming and transforming a bureaucratic identity. Journal of Immigrant \& Refugee Studies 1991;4:39-62, http://dx.doi.org/10. $1093 / \mathrm{jrs} / 4.1 .39$.
[51] Sundheds- og Ældreministeriet. Bekendtgørelse af Sundhedsloven. LBK nr 1188 af 24/09/2016, §80; 2016.

[52] Udlændinge- og Integrationsministeriet. Bekendtgørelse af udlændingeloven, LBK nr 1117 af 02/10/2017, §42a; 2017.

[53] Sundheds- og Ældreministeriet. Bekendtgørelse om forebyggende sundhedsydelser for børn og unge; 2010. p. 1-6.

[54] Udlændinge- I. Bekendtgørelse om tilbud om helbredsmæssig vurdering af nyankomne flygtninge og familiesammenførte til flygtninge BEK nr 979 af 28/06/2016; 2016.

[55] Dansk Røde Kors Asyl Psykologenheden. Standard for psykologiske screeninger af mindreårige asylansøgere; 2015.

[56] Sundhedsstyrelsen. Migranters sundhed; 2017 (Accessed 16 November 2017) https://www.sst.dk/da/sundhed-og-livsstil/migranter\#.

[57] Sundhedsstyrelsen. Orientering om sundhedsmæssige udfordringer i forbindelse med den aktuelle flygtningesituation. Til Regionerne, Asylcentrene; 2015.

[58] Socialstyrelsen. Faglige anvisninger til praktiserende læger og andre læger som gennemfører helbredsmæssige vurderinger af nyankomne flygtninge og familiesammenførte til flygtninge; 2015.

[59] The Danish Immigration Service. Contract between Danish Red Cross and the Danish Immigration Service on accommodation and support for asylumseekers by January $32017 ; 2017$.

[60] Inrikesministeriet. Lag om mottagande av personer som söker internationellt skydd och om identifiering av och hjälp till offer för människohandel 17.6.2011/746; 2011.

[61] Social- och Hälsovårdsministeriet. Hälso- och sjukvårdslag 30.12.2010/1326; 2010.

[62] National Institute for Health and Welfare (THL). Guidelines for health care services related to infection prevention. Infection prevention and vaccinations for asylum seekers; 2017 (Accessed 16 November 2017) https://www.thl. fi/en/web/infectious-diseases/what-s-new/information-to-special-groups/ infection-prevention-and-vaccinations-for-asylum-seekers.

[63] National Institute for Health and Welfare (THL). Notable symptoms and infectious diseases in asylum seekers; 2017 (Accessed 16 November 2017) https://www.thl.fi/en/web/infectious-diseases/what-s-new/information-tospecial-groups/infection-prevention-and-vaccinations-for-asylum-seekers/ notable-symptoms-and-infectious-diseases-in-asylum-seekers.

[64] Social- och Hälsovărdsministeriet. Förebyggandet av infektionsproblem hos flyktingar och asylsökanden Referat; 2009.

[65] Häkkinen H, IsoMauno J-T, Tyni T. Social- och hälsovårdstjänster för asylsökande på flyktingförläggningarna och kommunernas roll. Cirkulär 6/2016. Finlands Kommunförbund; 2016.

[66] Social- och Hälsovårdsministeriet. Rådgivningsverksamhet, skol- och studerandehälsovård samt förebyggande mun- och tandvård. Motiveringar till och tillämpningsanvisningar för förordningen (380/2009). Helsingfors; 2010.

[67] Social- och Hälsovårdsministeriet. Rätten till hälso- och sjukvårdstjänster Finland för barn och gravida kvinnor med invandrarbakgrund; 2017.

[68] Helse- og omsorgsdepartementet. Forskrift om rett til helse- og omsorgstjenester til personer uten fast opphold i riket. FOR-2011-12-16-1255; 2011.

[69] Helse- og omsorgsdepartementet. Forskrift om tuberkulosekontroll; 2009.

[70] Utlendingsdirektoratet. Informasjonsplan for barn og unge i mottak. RS 2009$041 ; 2009$.

[71] Utlendingsdirektoratet. Ung i Norge. Modul 07. Helse. n.d.

[72] Helsedirektoratet. Nasjonal faglig retningslinje for det helsefremmende og forebyggende arbeidet i helsestasjon, skolehelsetjeneste og helsestasjon for ungdom. IS-2582; 2017.

[73] Justitie-departementet. Lag om hälso- och sjukvård till vissa utlänningar som vistas i Sverige utan nödvändiga tillstånd. 2013:407; 2013.

[74] Socialstyrelsen. Senaste version av SOSFS 2011: 11. Socialstyrelsens föreskrifter och allmänna råd om hälsoundersökning av asylsökande m.fl.; 2012.

[75] Socialstyrelsen. Kroppsundersökning; 2015 (Accessed 28 November 2017) http://www.socialstyrelsen.se/vardochomsorgforasylsokandemedflera/ halsoundersokning/kroppsundersokning.

[76] Socialstyrelsen. Provtagning; 2015 (Accessed 28 November 2017) http://www.socialstyrelsen.se/vardochomsorgforasylsokandemedflera/ halsoundersokning/provtagning.

[77] Rikshandboken Barnhälsovård. Migration och barns hälsa [Barnhälsovård för barn som migrerat från andra länder]; 2017.

[78] Folkhälsomyndigheten. Vägledning inför hälsoundersökningar för migranter. Möten om hälsa; 2014.

[79] Folkhälsomyndigheten. Människor på flykt - vägledning om smittskydd till hälso- och sjukvården; 2015.

[80] Folkhälsomyndigheten. Vaccinationer till människor på flykt rekommendationer till hälso- och sjukvården; 2015.

[81] Socialstyrelsen \& Skolverket. Vägledning för elevhälsan; 2016. 